\title{
Nitrogen Regulation of Synthesis of the High Affinity Methylammonium Transport System of Escherichia coli
}

\author{
By LUIS SERVÍN-GONZÁLEZ AND FERNANDO BASTARRACHEA* \\ Centro de Investigación sobre Ingeniería Genética y Biotecnología, Universidad Nacional \\ Autónoma de México, Apartado Postal 70479, DF 04510, Mexico
}

(Received 28 February 1984; revised 2 July 1984)

\begin{abstract}
Uptake of ${ }^{14} \mathrm{CH}_{3} \mathrm{NH}_{3}^{+}$(methylammonium) was measured as a probe of $\mathrm{NH}_{4}^{+}$transport in intact Escherichia coli cells and derivatives impaired in the Ntr regulatory system. The results suggest that expression of the high affinity ${ }^{14} \mathrm{CH}_{3} \mathrm{NH}_{3}^{+}$transport system (a) requires de novo polypeptide synthesis, $(b)$ is activated by the $g \ln G$ and $g \ln F$ regulatory products under nitrogen limitation, and $(c)$ is repressed under nitrogen excess by the $g \ln L$ product. Cells deficient in glutamate synthase activity by virtue of their harbouring the gltB31 mutation were unable to activate synthesis of ${ }^{14} \mathrm{CH}_{3} \mathrm{NH}_{3}^{+}$transport. This could explain the inability of cells carrying glt $B$ mutations to grow on low concentrations of $\mathrm{NH}_{4}^{+}$.
\end{abstract}

\section{INTRODUCTION}

Most micro-organisms assimilate $\mathrm{NH}_{4}^{+}$ions as a sole source of nitrogen and must have mechanisms that ensure penetration of these cations. Some bacteria and fungi have mechanisms that concentrate ammonium ions intracellularly to 100 -fold or more across the cell envelope (see Brown, 1980, and Kleiner, 1981 for reviews). Stevenson \& Silver (1977) used ${ }^{14} \mathrm{CH}_{3} \mathrm{NH}_{3}^{+}$uptake to demonstrate an $\mathrm{NH}_{4}^{+}$transport system in Escherichia coli. A genetical analysis of the $\mathbf{N H}_{4}^{+}$ transport system has not been pursued in any prokaryote. We decided to determine whether the E. coli high affinity $\mathrm{NH}_{4}^{+}$transport system previously described by Stevenson \& Silver (1977) was under the general genetic control of nitrogen metabolism, as suggested for Klebsiella pneumoniae (Kleiner, 1982). In enteric bacteria the latter system, known as Ntr, regulates the expression of the glnALG operon (Pahel et al., 1982) and other genes or operons involved in the transport of several amino acids (Kustu et al., 1979a; Wei \& Kustu, 1981) and in the subsequent utilization of nitrogen sources such as arginine, proline or histidine (reviewed by Tyler, 1978; Magasanik, 1982). Ntr also regulates the expression of the complex nitrogenase system of $K$. pneumoniae (Streicher et al., 1974; de Bruijn \& Ausubel, 1981; Espin et al., 1981; Ow \& Ausubel, 1983) and Rhizobium meliloti (Sundaresan et al., 1983).

The products of at least three genes, $g \ln F, g \ln G$ and $g \ln L$, have been identified as the regulatory proteins involved in Ntr control (Kustu et al., 1979 b; McFarland et al., 1981; Pahel et al., 1982; Chen et al., 1982). Under conditions of nitrogen limitation, the $g \ln G$ product appears to act in concert with the $g \ln F$ product to activate all genes or operons under $\mathrm{Ntr}$ control. Under conditions of nitrogen excess, the $g \ln G$ product has been postulated to repress transcription of the same genes in concert with the $g \ln L$ product. The evidence presented here indicates that synthesis of the high affinity $\mathrm{NH}_{4}^{+}$transport system of $E$. coli is also subject to $\mathrm{Ntr}$ regulation.

\section{METHODS}

All strains used were $E$. coli K12 derivatives. All mutations affecting the Gln and Ntr phenotypes were introduced into MX614 (F-, thi $\Delta$ (pro-lac) ilv680 galE) either by mutation or by genetic manipulation (Covarrubias et al., 1980; Osorio et al., 1984), except for MX705, which is derived from strain RR1 (Covarrubias et al., 1980). 
Strains were grown aerobically in liquid NN minimal medium (Covarrubias et al., 1980) with $0 \cdot 2 \%$ glucose as carbon source, and the indicated nitrogen source. ${ }^{14} \mathrm{CH}_{3} \mathrm{NH}_{3}^{+}$was obtained from New England Nuclear $\left(50 \mathrm{mCi} \mathrm{mmol}^{-1} ; 1.8 \mathrm{GBq} \mathrm{mmol}^{-1}\right)$; specific activity was lowered to $5.0 \mathrm{mCi} \mathrm{mmol}^{-1}$ with nonradioactive $\mathrm{CH}_{3} \mathrm{NH}_{3}^{+} .{ }^{14} \mathrm{CH}_{3} \mathrm{NH}_{3}^{+}$uptake assays were performed as described by Stevenson \& Silver (1977) using $50 \mathrm{~mm}-$ Tris $/ \mathrm{HCl}, 72 \mathrm{~mm}-\mathrm{NaCl}, 0 \cdot 2 \%$ glucose $(\mathrm{pH} \mathrm{7.0)}$ ) as assay buffer, and substituting $\mathrm{M} 9$ medium for $\mathrm{NN}$ minimal medium. ${ }^{14} \mathrm{C}$ radioactivity was counted in a Packard TriCarb liquid scintillation spectrometer using $10 \mathrm{ml}$ Bray`s scintillation mixture per filter (Peng, 1977). Specific activity determinations are expressed as nmol methylammonium accumulated $\min ^{-1}$ ( $\mathrm{g}$ cell dry mass) ${ }^{-1}$. These were highly reproducible for duplicates of a given culture but varied from \pm 10 to $25 \%$ for independent cultures. Protein was determined by the method of Lowry. $\mathrm{L}-\left[\mathrm{U}-{ }^{14} \mathrm{C}\right]$ Glutamine was obtained from New England Nuclear; nonradioactive $\mathrm{CH}_{3} \mathrm{NH}_{3}^{+}$and amino acids were from Sigma. $\mathrm{NH}_{4}^{+}$concentrations were measured with an ammonium electrode (Beckman model 39565 ). Glutamine synthetase [L-glutamate : ammonia ligase (ADP-forming), EC 6.3.1.2.] activity was measured by the $\gamma$-glutamyl transferase assay (Covarrubias et al., 1980).

\section{RESULTS}

\section{General properties of the ${ }^{14} \mathrm{CH}_{3} \mathrm{NH}_{3}^{+}$transport system}

Several characteristics of the ${ }^{14} \mathrm{CH}_{3} \mathrm{NH}_{3}^{+}$high affinity transport system described by Stevenson \& Silver (1977) for E. coli strain ML308-225 were found in strain MX614 (Table 1). We confirmed: (a) uptake at $\mathrm{pH}$ values of 7 and 9, $(b)$ energy dependence of the concentrative uptake as shown by its inhibition by cyanide, $(c)$ inhibition of uptake by $\mathrm{NH}_{4}^{+}$ions but not by glutamate, and $(d)$ variability in the levels of uptake (Table 2). In addition we found that glutamine at concentrations equivalent to those of $\mathrm{NH}_{4}^{+}$ions strongly inhibited ${ }^{14} \mathrm{CH}_{3} \mathrm{NH}_{3}^{+}$uptake (Table 1). Since we found that at equivalent concentrations neither $\mathrm{CH}_{3} \mathrm{NH}_{3}^{+}$nor $\mathrm{NH}_{4}^{+}$ions inhibited L- $\left[{ }^{14} \mathrm{C}\right]$ glutamine uptake (data not shown), the possibility that we were measuring ${ }^{14} \mathrm{CH}_{3} \mathrm{NH}_{3}^{+}$transport via the high affinity glutamine transport system (Weiner \& Heppel, 1971; Willis et al., 1975; Betteridge \& Ayling, 1976) was ruled out. Contamination of our glutamine preparations with $\mathrm{NH}_{4}^{+}$ions was found to be of the order of less than $0 \cdot 14 \%$ by mass, too low to account for the inhibitory effect of glutamine.

\section{Activation and repression of ${ }^{14} \mathrm{CH}_{3} \mathrm{NH}_{3}^{+}$transport}

MX614 cells grown under nitrogen limitation ( $0.5 \mathrm{mM}-\mathrm{NH}_{4}^{+}$or $6.8 \mathrm{mM}$-glutamine) developed a high capacity for ${ }^{14} \mathrm{CH}_{3} \mathrm{NH}_{3}^{+}$uptake (Table 2). By contrast, cells grown with an excess of nitrogen $(15 \mathrm{~mm})$ or with a combination of $15 \mathrm{mM}-\mathrm{NH}_{4}^{+}$plus $6.8 \mathrm{mM}$-glutamine took up background amounts of ${ }^{14} \mathrm{CH}_{3} \mathrm{NH}_{3}^{+}$. These results suggest that synthesis of the ${ }^{14} \mathrm{CH}_{3} \mathrm{NH}_{3}{ }^{+}$transport system is regulated by nitrogen availability in a manner similar to that of several amino acid transport systems (Kustu et al., 1979a; Wei \& Kustu, 1981). The kinetics of activation of ${ }^{14} \mathrm{CH}_{3} \mathrm{NH}_{3}^{+}$transport was measured by transferring $\mathrm{MX} 614$ cells previously grown on $15 \mathrm{mM}-\mathrm{NH}_{4}^{+}$ to nitrogen limiting conditions. The ${ }^{14} \mathrm{CH}_{3} \mathrm{NH}_{3}^{+}$concentrative capacity increased significantly 60 min after the shift (Fig. 1a). The highest rate was observed when no nitrogen was added to the culture after the shift; a slightly lower rate was observed for cells grown on $0.5 \mathrm{mM}-\mathrm{NH}_{4}^{+}$and the lowest rate for those grown on glutamine. The highest rate obtained when no nitrogen was added following the shift cannot be taken as evidence to suggest that the lack of nitrogen is the event that triggers activation; these cells, even though they were washed after growth on $15 \mathrm{~mm}$ $\mathrm{NH}_{4}^{+}$, probably contained intracellular amounts of $\mathrm{NH}_{4}^{+}$ions which could act as the effector. The de novo synthesis of the ${ }^{14} \mathrm{CH}_{3} \mathrm{NH}_{3}{ }^{+}$carrier, and its polypeptide nature, were also suggested by the observation that chloramphenicol $\left(34 \mu \mathrm{g} \mathrm{ml}^{-1}\right)$ completely inhibited its formation under otherwise derepressing conditions (Fig. $1 a$ ). A slow repression was observed when MX614 cells fully activated for ${ }^{14} \mathrm{CH}_{3} \mathrm{NH}_{3}^{+}$transport were shifted to a $15 \mathrm{~mm}-\mathrm{NH}_{4}^{+}$medium (Fig. $1 b$ ). This slow onset of repression may be the consequence of a prolonged time required for cells to make active repressor, to a long half life of the previously synthesized carrier, or to both.

\section{Ntr regulation of synthesis of the ${ }^{14} \mathrm{CH}_{3} \mathrm{NH}_{3}^{+}$transport system}

${ }^{14} \mathrm{CH}_{3} \mathrm{NH}_{3}^{+}$uptake assays were performed on strains harbouring mutations in several genes known to be involved in Ntr regulation. The strains were grown under nitrogen limiting or 


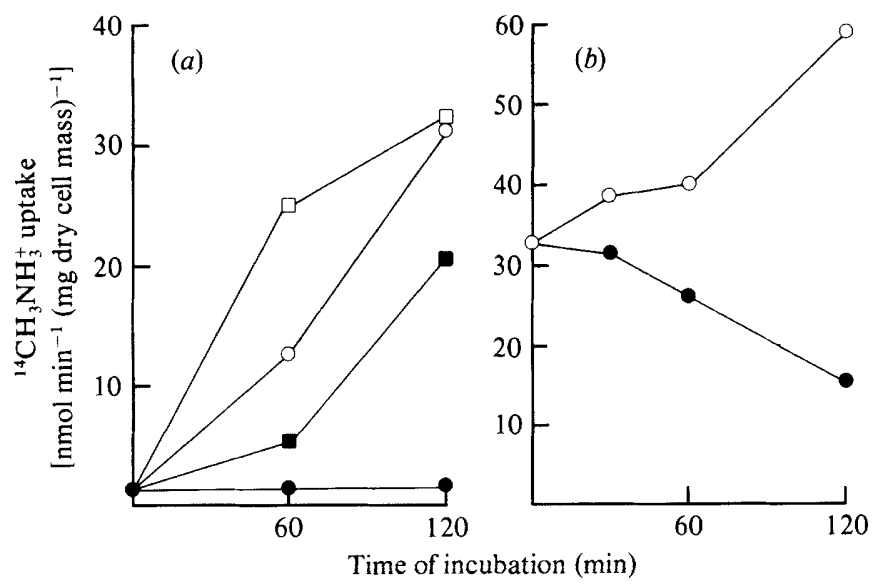

Fig. 1. Kinetics of derepression (a) and repression $(b)$ of the high affinity ${ }^{14} \mathrm{CH}_{3} \mathrm{NH}_{3}^{+}$transport system

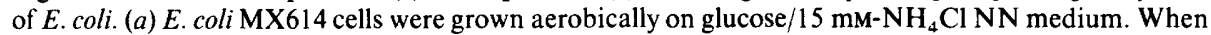
they reached a turbidity of $80 \mathrm{Klett}$ units they were washed three times and growth was continued in nitrogen limiting media, i.e. $0.5 \mathrm{mM}-\mathrm{NH}_{4} \mathrm{Cl}(\mathrm{O}), 6.8 \mathrm{mM}$-L-glutamine ( $\square$ ), or without nitrogen ( $\square$ ).

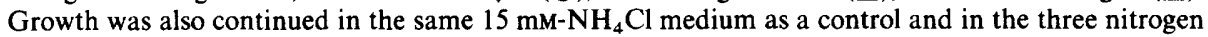
limiting media in the presence of $34 \mu \mathrm{g}$ chloramphenicol $\mathrm{ml}^{-1}$, all of which resulted in lack of derepression of ${ }^{14} \mathrm{CH}_{3} \mathrm{NH}_{3}^{+}$transport (O). (b) E. coli MX614 cells were grown aerobically on glucose $/ 0.5 \mathrm{mM}-$ $\mathrm{NH}_{4} \mathrm{Cl} \mathrm{NN}$ medium. When they reached a turbidity of $80 \mathrm{Klett}$ units the culture was divided and

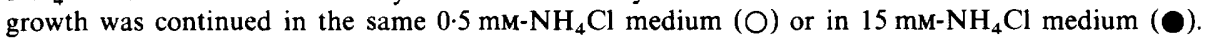
Samples were taken at appropriate intervals, washed, and tested for $6 \mu \mathrm{M}^{-14} \mathrm{CH}_{3} \mathrm{NH}_{3}^{+}$uptake.

\section{Table 1. Effect of inhibitors on ${ }^{14} \mathrm{CH}_{3} \mathrm{NH}_{3}^{+}$uptake by E. coli}

$E$. coli MX614 cells were grown aerobically on glucose/glutamine NN medium. When they reached a turbidity of $100 \mathrm{Klett}$ units they were washed twice and assayed for $6 \mu \mathrm{M}^{-1}{ }^{14} \mathrm{CH}_{3} \mathrm{NH}_{3}^{+}$uptake, as described in Methods. Inhibitors were added $5 \mathrm{~min}$ before reactions were started by addition of ${ }^{14} \mathrm{CH}_{3} \mathrm{NH}_{3}^{+}$. Results are the means of two experiments. ND, Not determined.

\begin{tabular}{|c|c|c|c|}
\hline \multirow[b]{2}{*}{ Addition } & \multicolumn{2}{|c|}{$\begin{array}{l}\text { Uptake }\left[\mathrm{nmol} \mathrm{min} \mathrm{min}^{-1}\right. \\
(\mathrm{g} \text { cell dry mass })^{-1} \text { ] }\end{array}$} & \multirow{2}{*}{$\begin{array}{l}\text { Percentage } \\
\text { inhibition } \\
\text { at } \mathrm{pH} 7 \cdot 0\end{array}$} \\
\hline & $\mathrm{pH} 7.0$ & $\mathrm{pH} 9.0$ & \\
\hline None & 13.8 & $19 \cdot 7$ & - \\
\hline $1 \mathrm{mM}-\mathrm{KCN}$ & 0.9 & ND & $93 \cdot 5$ \\
\hline $50 \mu \mathrm{M}-\mathrm{NH}_{+} \mathrm{Cl}$ & 0.4 & ND & $97 \cdot 1$ \\
\hline $50 \mu \mathrm{M}-\mathrm{L}-$ Glutamate & $12 \cdot 8$ & ND & $7 \cdot 2$ \\
\hline $50 \mu \mathrm{M}-\mathrm{L}-$ Glutamine & $0 \cdot 3$ & ND & 97.8 \\
\hline
\end{tabular}

Table 2. Effect of nitrogen availability on the capacity of $\mathrm{E}$. coli to synthesize a $\mathrm{CH}_{3} \mathrm{NH}_{3}^{+}$ transport system

See Table 1 for growth and assay conditions. Results are the means of three experiments $\pm \mathrm{SE}$.

Nitrogen source

$15 \mathrm{mM}^{-} \mathrm{NH}_{4} \mathrm{Cl}$

$0.5 \mathrm{mM}^{-\mathrm{NH}_{4} \mathrm{Cl}}$

$6.8 \mathrm{~mm}-\mathrm{L}$-Glutamine

$15 \mathrm{mM}^{-} \mathrm{NH}_{4} \mathrm{Cl}+$

$6.8 \mathrm{~mm}-\mathrm{L}-\mathrm{Glutamine}$

$$
\begin{gathered}
{ }^{14} \mathrm{CH}_{3} \mathrm{NH}_{3}^{+} \text {uptake } \\
{\left[\mathrm{nmol} \min ^{-1} \text { (g cell dry mass) }^{-1}\right. \text { ] }} \\
0.6 \pm 0 \cdot 1 \\
61 \cdot 6 \pm 6.3 \\
16.6 \pm 3.9 \\
1 \cdot 1 \pm 0.3
\end{gathered}
$$


Table 3. Glutamine synthetase activity and ${ }^{14} \mathrm{CH}_{3} \mathrm{NH}_{3}^{+}$uptake by E. coli strains grown under nitrogen limiting or excess conditions

Strains were grown under nitrogen limiting $\left(6.8 \mathrm{~mm}\right.$-glutamine) or excess $\left(15 \mathrm{~mm}-\mathrm{NH}_{4} \mathrm{Cl}\right)$ conditions. See Table 1 and Methods for growth and assay conditions. Representative results from several experiments are shown.

\begin{tabular}{|c|c|c|c|c|c|}
\hline \multirow[b]{2}{*}{ Strain } & \multirow[b]{2}{*}{ Relevant genotype } & \multicolumn{2}{|c|}{$\begin{array}{l}\text { Glutamine synthetase activity } \\
{\left[\text { nmol } \min ^{-1}(\text { mg protein })^{-1}\right]}\end{array}$} & \multicolumn{2}{|c|}{$\begin{array}{c}{ }^{14} \mathrm{CH}_{3} \mathrm{NH}_{3}^{+} \text {uptake } \\
{\left[\mathrm{nmol} \mathrm{min}{ }^{-1}(\mathrm{~g} \text { cell dry mass })^{-1}\right]}\end{array}$} \\
\hline & & $15 \mathrm{mM}^{-\mathrm{NH}_{4} \mathrm{Cl}}$ & $6.8 \mathrm{~mm}-\mathrm{L}$-Glutamine & $15 \mathrm{mM}-\mathrm{NH}_{4} \mathrm{Cl}$ & $6.8 \mathrm{~mm}-\mathrm{L}$-Glutamine \\
\hline MX614 & Wild-type & 150 & 1270 & 0.6 & $16 \cdot 6$ \\
\hline MX705 & $g \ln A 70$ & NG & $<10$ & NG & $0 \cdot 2$ \\
\hline MX727 & $g \ln A 71:: \operatorname{Tn} 5$ & NG & $<10$ & NG & $0 \cdot 4$ \\
\hline MX852 & $\Delta(g \ln A)$ & NG & $<10$ & NG & 0.6 \\
\hline MX856 & $g \ln D 84$ & NG & 50 & NG & 0.5 \\
\hline MX902 & $g \ln G 74:: \operatorname{Tn} 5$ & 50 & 50 & ND & 0.6 \\
\hline MX960 & $g \ln L 82:: \operatorname{Tn} 5$ & 80 & 230 & 0.5 & $0 \cdot 3$ \\
\hline MX1019 & $g \ln L 83$ & 1190 & 1910 & 3.7 & $8 \cdot 2$ \\
\hline MX1029 & $g \ln L 82:: T n 5 \ln G 85$ & 1170 & 2030 & $5 \cdot 0$ & 6.0 \\
\hline MX848 & $g \ln F 73:: \operatorname{Tn} 5$ & NG & $<10$ & NG & 0.5 \\
\hline MX988 & glt $B 31$ & 110 & 260 & ND & 0.5 \\
\hline
\end{tabular}

ND, Not done; NG, no growth.

excess conditions. None of the strains carrying mutations that lead either to the $\mathrm{Gln}^{-}$or the $\mathrm{Ntr}^{-}$phenotypes, or both, were able to activate synthesis of the ${ }^{14} \mathrm{CH}_{3} \mathrm{NH}_{3}^{+}$transport system. The strains tested carried mutations in either $g \ln A, g \ln F, g \ln G$ or $g \ln D$. This last mutation, by affecting the ability of $E$. coli cells to synthesize uridylyltransferase, leads to low levels of highly adenylylated glutamine synthetase and to the $\mathrm{Gln}^{-} \mathrm{Ntr}^{-}$phenotypes (Bloom et al., 1978). Strains MX705 and MX727 probably owe their $\mathrm{Ntr}^{-}$phenotype to polarity effects excerted by their $g \ln A$ mutations on $g \ln G$ expression.

We also examined two strains with mutations in the $g \ln L$ gene. One of these, MX1019, carries the $g \ln L 83$ mutation which we assume is non-polar to $g \ln G$ due to its ability to exhibit the GlnC and NtrC phenotypes. The other strain, MX960, carries the $g \ln L 82:: \operatorname{Tn} 5$ mutation which seems to be polar to $g \ln G$ as suggested by its $\mathrm{G} \ln \mathrm{R}$ and $\mathrm{Ntr}^{-}$phenotypes. MX960 cells were unable to activate synthesis of the ${ }^{14} \mathrm{CH}_{3} \mathrm{NH}_{3}^{+}$transport system whereas MX1019 cells did so (Table 3). Moreover, MX1019 cells built up a capacity to transport ${ }^{14} \mathrm{CH}_{3} \mathrm{NH}_{3}^{+}$under both nitrogen limitation or excess, i.e. they were constitutive for ${ }^{14} \mathrm{CH}_{3} \mathrm{NH}_{3}{ }^{+}$transport as well as for glutamine synthetase (Table 3).

A mutation tightly linked to $g \ln L 82:: \operatorname{Tn} 5$ was isolated in strain MX960. The new strain, MX1029, carried in addition to $g \ln L 82:: \mathrm{Tn} 5$ a secondary mutation tentatively termed $g \ln G 85$ which probably acts by relieving the polarity excerted by $g \ln L 82:: \mathrm{Tn} 5$ on $g \ln G$ (J. C. Urbina \& F. Bastarrachea, unpublished results). MX1029 turned out to be GlnC and NtrC, and thus constitutive for both ${ }^{14} \mathrm{CH}_{3} \mathrm{NH}_{3}^{+}$transport and glutamine synthetase (Table 3). Whether $g \ln G 85$ affects a $g \ln G$ regulatory region or creates a strong promoter within Tn5 in MX1029 cells, has not been determined.

In E. coli, the gltB gene which maps at minute 68 of the standard map (Pahel et al., 1978) is said to code for glutamate synthase [L-glutamate : $\mathrm{NADP}^{+}$oxidoreductase (transaminating), EC 1.4.1.13]. Cells carrying the gltB mutation were also unable to activate synthesis of their ${ }^{14} \mathrm{CH}_{3} \mathrm{NH}_{3}^{+}$transport system. These results are in agreement with previous ones (Pahel et al., 1978 ) showing that glt $B$ mutants of $E$. coli fail to grow or grow poorly on $\mathrm{NH}_{4}^{+}$ion concentrations lower than $0.1 \mathrm{mM}$ or on nitrogen sources such as arginine or proline, i.e. they are $\mathrm{Ntr}^{-}$.

It is known that $g l t B$ mutations are suppressed to $\mathrm{Ntr}^{+}$by $g \ln L$ secondary mutations (Pahel $e t$ al., 1978). Interestingly, while the $g \ln L 82:: \operatorname{Tn} 5$ mutation alone was unable to suppress the $\mathrm{Ntr}^{-}$ phenotype conferred by the gltB31 mutation, it did so in combination with $g \ln G 85$ as well as did $g \ln L 83$ (data not shown). The $g \ln G 85$ mutation apparently allows synthesis of the $g \ln G$ product in a constitutive manner (J. C. Urbina \& F. Bastarrachea, unpublished results). Mutations 
leading to $g \ln G$ constitutivity provide $E$. coli cells with a potential constitutivity for all $\mathrm{Ntr}$ regulated systems (NtrC), since the other product required for activation, the $g \ln F$ product, is naturally constitutive (Castaño \& Bastarrachea, 1984).

All the ${ }^{14} \mathrm{CH}_{3} \mathrm{NH}_{3}^{+}$uptake assays described in Table 3 were carried out at $\mathrm{pH} 7 \cdot 0$. The fact that strains MX902 (glnG74:: Tn5) and MX988 (gltB3l) failed to take up ${ }^{14} \mathrm{CH}_{3} \mathrm{NH}_{3}^{+}$at pH 9.0 (specific activities of 0.8 and 1.7 , respectively; data not shown), apparently indicates that the same carrier is responsible for the transport of ${ }^{14} \mathrm{CH}_{3} \mathrm{NH}_{3}^{+}$at either $\mathrm{pH}$ value.

Collectively these results provide good evidence that the products of $g \ln G$ and $g \ln F$ are required to activate expression of the ${ }^{14} \mathrm{CH}_{3} \mathrm{NH}_{3}^{+}$carrier system, and that a functional $g \ln L$ product is necessary to achieve its repression. They also suggest that a functional $g \ln L$ product is not necessary for its activation.

\section{DISCUSSION}

Our results confirm and extend those of a previous report by Stevenson \& Silver (1977) on the capacity of $E$. coli cells to express an energy-dependent concentrative uptake system for ${ }^{14} \mathrm{CH}_{3} \mathrm{NH}_{3}^{+}$. Moreover, the results show that this system is activated by growth of cells under nitrogen limitation and repressed under conditions of nitrogen excess. Synthesis of the ${ }^{14} \mathrm{CH}_{3} \mathrm{NH}_{3}^{+}$carrier showed a strict dependence for de novo polypeptide synthesis, as demonstrated by its inhibition by chloramphenicol. Once activated, ${ }^{14} \mathrm{CH}_{3} \mathrm{NH}_{3}^{+}$uptake could be inhibited by $\mathrm{NH}_{4}^{+}$ions but not by glutamate. Surprisingly, ${ }^{14} \mathrm{CH}_{3} \mathrm{NH}_{3}{ }^{+}$uptake was also inhibited by glutamine. Further evidence suggested that ${ }^{14} \mathrm{CH}_{3} \mathrm{NH}_{3}^{+}$does not enter the cells via the high affinity glutamine transport system. Glutamine inhibition of ${ }^{14} \mathrm{CH}_{3} \mathrm{NH}_{3}^{+}$uptake is difficult to explain on the basis of a structural similarity between these compounds that would allow their competition for binding at the carrier molecule. On the other hand, if we invoke the formation of a metabolic product of glutamine as responsible for the inhibition, an immediate mol per mol conversion of glutamine into $\mathrm{NH}_{4}^{+}$ions (and glutamate) should take place in order for cells to attain the $0.05 \mathrm{~mm}$ external concentration required to inhibit ${ }^{14} \mathrm{CH}_{3} \mathrm{NH}_{3}^{+}$transport by $90 \%$ (Table 1). The fact that glutamine acts as a nitrogen limiting substrate for activation of expression of ${ }^{14} \mathrm{CH}_{3} \mathrm{NH}_{3}^{+}$transport further suggests that a high external concentration of $\mathrm{NH}_{4}^{+}$ ions is not built up by $E$. coli cells when they are grown on $6.8 \mathrm{mM}$-glutamine $\left(1 \mathrm{mg} \mathrm{m}^{-1}\right)$ as the only nitrogen source. If such were the case, they would be unable to activate their ${ }^{14} \mathrm{CH}_{3} \mathrm{NH}_{3}^{+}$ transport system under this condition. More experimentation is required to explain the nature of the inhibition of ${ }^{14} \mathrm{CH}_{3} \mathrm{NH}_{3}^{+}$uptake by glutamine.

Results presented in Tables 2 and 3 show that in wild-type $E$. coli cells synthesis of both glutamine synthetase and ${ }^{14} \mathrm{CH}_{3} \mathrm{NH}_{3}^{+}$transport are simultaneously activated by nitrogen limitation and repressed by conditions of nitrogen excess. By use of mutants affected in Ntr regulation we demonstrated that both $g \ln G$ and $g \ln F$ products are required to activate synthesis of the ${ }^{14} \mathrm{CH}_{3} \mathrm{NH}_{3}^{+}$transport system. The results also show that the $g \ln L$ product is required for its repression. Mutation $g \ln L 83$ or the combination $g \ln L 82:: T n 5$-glnG85 leads to constitutivity of both glutamine synthetase and ${ }^{14} \mathrm{CH}_{3} \mathrm{NH}_{3}^{+}$transport. Even though strains MX1019 $(\mathrm{g} \ln L 83)$ and MX1029 (glnL82::Tn5-glnG85) were constitutive, they were unable to attain full derepression for both ${ }^{14} \mathrm{CH}_{3} \mathrm{NH}_{3}^{+}$uptake and glutamine synthetase, particularly when grown on $15 \mathrm{~mm}-\mathrm{NH}_{4}^{+}$medium (Table 3). An explanation for this is not available. It could be related to the fact that the control region of the $g \ln A L G$ operon has three potential promoters (Covarrubias \& Bastarrachea, 1983), the functionality of which have not been ascertained. We still do not know how they respond to different physiological conditions or to qualitative and quantitative changes of the $g \ln G$ and $g \ln L$ regulatory proteins.

Finally, we found that MX988 cells carrying the gltB31 mutation are also impaired in their ability to activate expression of ${ }^{14} \mathrm{CH}_{3} \mathrm{NH}_{3}^{+}$transport and to derepress glutamine synthetase fully (Table 3). These results were expected, since gltB mutants are known to be affected in their ability to synthesize glutamate synthase, to be phenotypically $\mathrm{Ntr}^{-}$(Pahel et al., 1978) and unable to increase their levels of glutamine synthetase in response to nitrogen limitation (Magasanik, 1982). The inability of gltB3I cells to activate synthesis of their ${ }^{14} \mathrm{CH}_{3} \mathrm{NH}_{3}^{+}$ 
transport system strongly suggests this, rather than the high substrate $K_{\mathrm{m}}$ values of glutamate dehydrogenase (Tyler, 1978), as the most likely explanation for their inability to grow on low $\mathrm{NH}_{4}^{+}$ion concentrations. The reasons for the failure of cells carrying glt $B$ mutations to activate other Ntr regulated systems, however, is still unknown.

We are grateful to J. C. Urbina and A. Osorio for some of the glutamine synthetase activity determinations, and to David G. Patriquin for his review of the manuscript. This work was supported, in part, by a research grant from the Consejo Nacional de Ciencia y Tecnología (Mexico).

\section{REFERENCES}

Betteridge, P. R. \& Ayling, P. D. (1976). The regulation of glutamine transport and glutamine synthetase in Salmonella typhimurium. Journal of General Microbiology 95, 324-334.

Bloom, F. R., Levin, M. S., FoOR, F. \& Tyler, B. (1978). Regulation of glutamine synthetase formation in Escherichia coli: characterization of mutants lacking uridylyltransferase. Journal of Bacteriology 134, 569-577.

Brown, C. M. (1980). Ammonia assimilation and utilization in bacteria and fungi. In Microorganisms and Nitrogen Sources, pp. 511-535. Edited by J. W. Payne. Chichester: John Wiley \& Sons.

DE Bruijn, F. J. \& Ausubel, F. M. (1981). The cloning and transposon $\operatorname{Tn} 5$ mutagenesis of the $g \ln A$ region of Klebsiella pneumoniae: identification of $g \ln R$, a gene involved in the regulation of the nif and hut operons. Molecular and General Genetics 183, 289297.

CAStaño, I. \& Bastarrachea, F. (1984). glnF-lacZ fusions in Escherichia coli: studies on $g \ln F$ expressions and its chromosomal orientation. Molecular and General Genetics 195, 228-233.

Chen, Y.-M., Backman, K. \& Magasanik, B. (1982). Characterization of a gene, $g \ln L$, whose product is involved in the regulation of nitrogen utilization in Escherichia coli. Journal of Bacteriology 150, 214-220.

Covarrubias, A. A. \& Bastarrachea, F. (1983). Nucleotide sequence of the $g \ln A$ control region of Escherichia coli. Molecular and General Genetics 190, 171-175.

Covarrubias, A. A., Sanchez-Pescador, R., Osorio, A., Bolivar, F. \& Bastarrachea, F. (1980). ColEl hybrid plasmids containing Escherichia coli genes involved in the biosynthesis of glutamate and glutamine. Plasmid 3, 150-164.

Espin, G., Alvarez-Morales, A. \& Merrick, M. (1981). Complementation analysis of $g \ln A$-linked mutations which affect nitrogen fixation in Klebsiella pneumoniae. Molecular and General Genetics 184, 213-217.

KLEINER, D. (1981). The transport of $\mathrm{NH}_{3}$ and $\mathrm{NH}_{4}^{+}$ across biological membranes. Biochimica et biophysica acta 639, 41-52.

KLEINER, D. (1982). Ammonium (methylammonium) transport by Klebsiella pneumoniae. Biochimica et biophysica acta 688, 702-708.

Kustu, S. G., McFarland, N. C., Hui, S. P., Esmon, B. \& AmEs, G. F. (1979a). Nitrogen control in Salmonella typhimurium: co-regulation of synthesis of glutamine synthetase and amino acid transport systems. Journal of Bacteriology 138, 218-234.

Kustu, S., Burton, D., Garcia, E., McCarter, L. \&
McFarland, N. $(1979 b)$. Nitrogen control in Salmonella: regulation by the $g \ln R$ and $g \ln F$ gene products. Proceedings of the National Academy of Sciences of the United States of America 76, 45764580.

MaGaSANIK, B. (1982). Genetic control of nitrogen assimilation in bacteria. Annual Review of Genetics 16, 135-168.

McFarland, N., McCarter, L., Artz, S. \& Kustu, S. (1981). Nitrogen regulatory locus ' $g \ln R$ ' of enteric bacteria is composed of cistrons $n t r B$ and $n t r C$ : identification of their products. Proceedings of the National Academy of Sciences of the United States of America 78, 2135-2159.

Osorio, A. V., Servin-Gonzalez, L., Rocha, M., Covarrubias, A. A. \& Bastarrachea, F. (1984). cisdominant, glutamine synthetase constitutive mutations of Escherichia coli independent of activation by the $g \ln G$ and $g \ln F$ products. Molecular and General Genetics 194, 114-123.

OW, D. W. \& Ausubel, F. M. (1983). Reguation of nitrogen metabolism genes by nif $A$ gene product in Klebsiella pneumoniae, Nature, London 301, 307-313.

Pahel, G., Zelenetz, A. D. \& TYler, B. (1978). gltB gene and regulation of nitrogen metabolism by glutamine synthetase in Escherichia coli. Journal of Bacteriology 133, 139-148.

Pahel, G., Rothstein, D. M. \& Magasanik, B. (1982). Complex $g \ln A-g \ln L-g \ln G$ operon of Escherichia coli. Journal of Bacteriology 150, 202-213.

Peng, C. T. (1977). Sample Preparation in Liquid Scintillation Counting. Amersham, UK: Amersham International.

SteVenson, R. \& Silver, S. (1977). Methylammonium uptake by Escherichia coli: evidence for a bacterial $\mathrm{NH}_{4}^{+}$transport system. Biochemical and Biophysical Research Communications 75, 1133-1139.

Streicher, S. L., Shanmugan, K. T., Ausubel, F., MORANDI, C. \& GOLDBERG, R. B. (1974). Regulation of nitrogen fixation in Klebsiella pneumoniae: evidence for a role of glutamine synthetase as a regulator of nitrogenase synthesis. Journal of Bacteriology 120, 815-821.

Sundaresan, V., Ow, D. W. \& Ausubel, F. M. (1983). Activation of Klebsiella pneumoniae and Rhizobium meliloti nitrogenase promoters by $g \ln (n t r)$ regulatory proteins. Proceedings of the National Academy of Sciences of the United States of America 80, 40304034.

TYLER, B. (1978). Regulation of the assimilation of nitrogen compounds. Annual Review of Biochemistry 47, $1127-1162$.

WEI, G. R. \& Kustu, S. (1981). Glutamine auxotrophs 
with mutations in a nitrogen regulatory gene, $n t r C$, that is near $\ln A$. Molecular and General Genetics 183, 392-399.

WeINER, J. H. \& HePpel, L. A. (1971). A binding protein for glutamine and its relation to active transport in Escherichia coli. Journal of Biological Chemistry 246, 6933-6941.

Willis, R. C., IwatA, K. K. \& Furlong, C. E. (1975). Regulation of glutamine transport in Escherichia coli. Journal of Bacteriology 122, 1032-1037. 